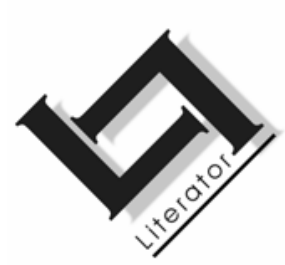

\title{
Promoting children's literature: The challenges and possibilities of using the Internet in a developing society
}

Franci Greyling

School of Languages

Potchefstroom Campus

North-West University

POTCHEFSTROOM

E-mail: sktsfg@puknet.puk.ac.za

\begin{abstract}
Promoting children's literature: The challenges and possibilities of using the Internet in a developing society
\end{abstract}

This article explores the possibilities and practicalities of using the Internet in a multicultural society such as South Africa to the benefit of language and cultural identity, media literacy and children's literature. Stories create opportunities for worlds to meet and for cultural and language identities to be formed - especially in the minds of children. It is thus of crucial importance that children's literature should be available and advanced in all indigenous languages. The Internet, the information and communication technology of the future, can play a significant role in the creation and transference of cultural identity, including the advancement of indigenous languages in general, and literature and literacy in particular. The vast technical possibilities of the Internet, its cost-efficiency and interactive and inviting character make it an important option to consider for the advancement of children's literature. Although access to the Internet in South Africa is still relatively limited, the importance of new communication technologies is recognised by various policies, the implementation of which could result in the accessibility of electronic media and the literacy of its users. With "Storiewerf", an existing website for Afrikaans children's literature as a working example, new websites can be developed to provide content and services for other target groups as well. 


\section{Opsomming}

Die bevordering van kinderliteratuur: uitdagings vir en moontlikhede van die gebruik van die Internet in 'n ontwikkelende gemeenskap

Dié artikel verken die moontlikhede en praktiese implikasies om die Internet in 'n multikulturele gemeenskap soos Suid-Afrika te gebruik tot voordeel van taal- en kulturele identiteit, mediageletterdheid en kinder- en jeugliteratuur. Stories bied die geleentheid vir wêrelde om te ontmoet en vir die vorming van kulturele en taalidentiteit - dit geld veral ten opsigte van kinders. Dit is daarom uiters belangrik dat kinderliteratuur in alle inheemse tale beskikbaar is en bevorder word. Die Internet, as die inligting- en kommunikasietegnologie van die toekoms, kan 'n belangrike rol speel in die skep en oordrag van kulturele identiteit en die bevordering van inheemse tale, letterkunde en geletterdheid. Vanweë die tegniese moontlikhede,die kosteeffektiwiteit en die interaktiewe en uitnodigende aard van die Internet is dit 'n belangrike opsie om te oorweeg vir die bevordering van kinderliteratuur. In Suid-Afrika het betreklik min mense reeds toegang tot die Internet; nogtans word die belangrikheid van die nuwe kommunikasietegnologie deur staatsbeleid erken, en so ook die feit dat die toepassing daarvan kan bydra tot die beskikbaarheid van elektroniese media en die geletterdheid van gebruikers. Met "Storiewerf", 'n bestaande webtuiste vir Afrikaanse kinderliteratuur as voorbeeld, kan nuwe webtuistes ontwikkel word om inhoud en dienste vir ' $n$ verskeidenheid teikengroepe te verskaf.

\section{Introduction}

Stories are important. Through stories in their various forms one acquires language, knowledge and wisdom, shares ideas, makes friends, discovers worlds and extends horizons. Stories also create opportunities for worlds to meet and for cultural and language identities to be formed - especially in the minds of children.

We are living in the Electronic Era, in a world getting smaller, with electronic media as the communication route of the day and the Internet as the highway to information. This phenomenon, it seems, will also hold true for the future. This given implies that children, and literature for children, also need to communicate through this new media.

Burnett and Marshall (2003:61), for instance, remark:

Information and communication technology shapes our perception, distributes our pictures of the world to one another, and constructs different forms of control over the cultural stories that shape our sense of who we are in our world. The instant 
we develop a new technology of communication - talking drums, papyrus scrolls, books, telegraph, radios, televisions, computers, mobile phones - we at least partially reconstruct the self and its world, creating new opportunities for reflection, perception, and social experience.

Despite concerns regarding the negative influence of the Internet (e.g. globalisation, ousting of smaller languages and national identity, technology versus oral tradition, etcetera) the Internet can also be utilised to counteract these influences and become a positive force in identity formation and cultural transition.

This article thus explores the possibilities and practicalities of using the Internet in a multicultural society such as South Africa to the benefit of language and cultural identity, media literacy and children's literature.

\section{The Internet, language and identity}

One of the results of communication via the Internet is a growing tendency towards globalisation, including linguistic globalisation. Concern is expressed worldwide about the dominance of English on the Internet (Wallraff, 2000; Wasserman, 2003). Currently approximately $68 \%$ of Web content is in English, although it is estimated that $65 \%$ of online language communities are not native Englishspeakers (Global Reach, 2003a; 2003b). (Statistics among different polls may vary significantly.)

Burnett and Marshall (2003:79) observe that although the sense of English as the lingua franca of the Web and the Internet is powerfully established, the "English" hold on the Web is increasingly tenuous. They contribute this to the fact that the Web is both an expression of work identity and leisure identity. The expansion of the Internet in Asia and China in particular is shifting the language balance. The tendency for non-English speakers logging on to search out content in their own languages is increasing, as pointed out by other observers (compare Wallraff, 2000; Dix, 2003). This demand for and use of languages other than English on the Internet coincide with a growing sensitivity towards the significance of cultural and linguistic diversity, as referred to by the National Research Foundation (2003).

In their article "Indigenous Languages and the Internet: With LitNet as a case study", Kaschula and De Vries (2000) postulate that a direct correlation exists between people's access to the Internet and 
the use of languages other than English on the Internet. The demand for and use of languages on the Internet result in the empowerment of these languages. Access to the Internet, the use of this new media and the advancement of indigenous languages are intertwined.

The Internet allows communities to be formed without the encumbrance of physical borders. Virtual communities organised around shared interests or purposes (e.g. language, interests, ideological premises) have the potential of providing a user with a sense of belonging and identity. The Internet is in a position to link or join together, and this advantage could also lead to a sense of closer connection within language communities, regardless of where the speakers live (Kaschula \& De Vries, 2000).

In the article, "Globalisation, the Internet and South African languages", Wasserman (2003) discusses the potential of the Internet to empower South African minority languages, and outlines the new possibilities for cultural empowerment opened by the Internet. According to Wasserman (2003:89) the Internet in South Africa already shows potential for the empowerment of minority languages, advancement of multilingualism and the creation of collective virtual space. The realisation of this potential, however, depends on the availability of access to the Internet. Financial factors thus play a significant role in the actual realisation of the Internet's potential.

The South African Constitution enshrines a multilingual language policy, protecting the use and status of all the official languages in South Africa. The Constitution states that the eleven official languages should enjoy parity of esteem and must be treated equitably, and that the state should make policies to promote multilingualism and enhance the status of marginalised languages.

Recognising the historically diminished use and status of the indigenous languages of our people, the state must take practical and positive measures to elevate the status and advance the use of these languages (South Africa, 1996).

The Constitution also states that government should communicate with the public in more than one language; that every South African has the right to speak the language of her or his choice; that education through the mother tongue is a basic human right; that communities have the right to maintain their cultures and languages; that defendants have the right to be tried in a language they 
understand; and that discrimination on grounds of language is outlawed (South Africa, 1996; i-MAG, 2004).

In order to create a legislative and policy framework a National Language Policy Framework was accepted, which binds government in the following ways: government should use all languages when communicating with the citizens of the country, state departments, such as the Departments of Education and of Communications, have instituted laws and policies that strive towards multilingualism in various public domains. Public bodies, such as the Pan South African Language Board (PANSALB), have also been set up to promote multilingualism (i-MAG, 2004).

In a media statement of 27 April 2004 by the Multilingualism Action Group (i-MAG), "Speaking freely on Freedom Day", the progress towards individual language rights came under scrutiny. Progress that has been made to create a legislative and policy framework is acknowledged, while concern is expressed about its practical implementation:

However, we are concerned about the failure to translate such policies and laws into practice - a failure that could at least partly be ascribed to a lack of political will, and an unwillingness to make available the necessary funds and other resources. For the average South African - and especially for the majority who are not proficient in English - the promised freedom has not yet translated into linguistic freedom.

Against this background it is clear that although the state has the legal responsibility to guarantee individual language rights and multilingualism, the public and individual speech communities have to take joint responsibility for the practical implementation of these. The practical implementation of language rights includes the use of the Internet and the creation of websites in and for all South African languages.

The Internet is a much more inexpensive medium for the distribution of information than the printed media (Wasserman, 2003:86). The tools to create and publish a website are relatively easy to use and freely available as shareware, thus providing possibilities of publication to the individual. Burnett and Marshall (2003:75) emphasise this aspect of the Web and the freedom and power it contains within:

The Web has at the very least been successful at offering this promise of production to its users. Because of its relative 
newness, the Web puts in relief the politics of cultural production that have been buried in past struggles and contestations in previous media forms.

The related opportunities of power and freedom do not apply only to the creator of a website or Internet application, but also allow for the individual user to achieve the following aims: to change and shape a particular website and the Internet to his or her liking, to receive the information he/she chooses, to participate via various interactive means, and even to publish his/her own work on the Internet (compare Burnett \& Marshall, 2003:68; Wasserman, 2003:84).

Every group or individual with access to the Internet may thus use it as a means of reconstructing the self and his/her world, and as a means of finding new opportunities for reflection, perception, and social experience (Burnett \& Marshall, 2003:61).

The Internet can play a significant role in the creation and transference of cultural identity, including the advancement of indigenous languages in general, and literature and literacy in particular. Kaschula and De Vries (2000) encourage writers of all of South Africa's languages to make use of sites such as the literary journal LitNet (www.litnet.co.za). In doing so they will have their literary contributions placed online, have the opportunity to air their views in the letter pages, and also make a contribution by submitting their academic work in indigenous languages.

\section{Literacy, language and children's literature}

In multicultural South Africa, with its population of 45 million people, vast socio-economic differences and diverse levels of literacy are apparent. Concern about the high levels of illiteracy is widely expressed. Investigations show an alarmingly high level of illiteracy among adults and youth alike, and low levels of scientific and mathematical literacy among students (National Research Foundation, 2003). In the age group $20^{+}$years $17,9 \%$ have never received any education and $30,8 \%$ completed only a part of their high school education (National Census, 2001). A nationwide survey among 52000 pupils indicates that the average Grade 3 learner scores $54 \%$ for literacy and $30 \%$ for numeracy (Anon., 2003).

Reasons for the current situation include the following aspects: learning in a second language, which has been shown to create a situation in which the assimilation of knowledge is severely impaired; parental choice for an English approach; the heterogeneous nature 
of urban schools and institutions of learning; and the mismatch in language competence of pupils and teachers (National Research Foundation, 2003).

This situation clearly has a bearing on the current status of written children's literature in the different South African languages.

In general, children's books in South Africa receive little attention. Few publications review children's books and major book stores mainly stock and promote international publications (mainly British). Owing to severe budget cuts many school libraries have had to close, while public library services are no longer able to buy sufficient books to provide for the broader population (Sisulu, 2004:2). As a result of these tendencies parents often report that they cannot find appropriate reading matter for their children. While this is true for local Afrikaans and English children's books, the situation is even more desperate for children's literature in the other nine official languages. Despite numerous attempts by publishers to produce and market children's books in the other indigenous languages, booksellers seldom keep them in stock and the books are left unsold in warehouses (Galloway, 2002; Du Plessis, 2003).

Elinor Sisulu (2004), in the editorial of Cape Librarian, emphasises some of the problems:

Despite a favourable policy environment, and the fact that much has been achieved in the past ten years, we still face similar problems in book development and publishing in South Africa to those found elsewhere in Africa. These include shortage of capital and skills, less than adequate marketing and distribution structures, low levels of literacy, and the lack of a reading culture.

Sisulu (2004) reiterates: "I believe passionately in the need to lobby continuously for increased investment in the three l's - language, literature, and libraries."

It may also be asked whether the Internet is a possible medium for the advancement of language, literature and libraries in Africa, or whether the use of this new medium is counterproductive, in light of the strong oral tradition of African languages.

The French philosopher, Régis Debray, identified three media spheres, namely the logo sphere, the grapho sphere and the video sphere (Stassen, 2003). Characteristic of each sphere is cultural transmittance primarily via this particular sphere: the spoken word 
(logo sphere), written word (grapho sphere) and image (video sphere). In his article, "Die laaste (Afrikaanse) boek?", Stassen (2003) indicates that ours is the time of transition between the book (paper-based written word) and the Internet (screen-based written word). Although the Internet still forms part of the grapho sphere, the video sphere is becoming more important. The status of the book is also affected by this transition (Stassen, 2003). In Africa the oral tradition (logo sphere) had for centuries been the way in which cultural transmittance took place. Even today Africa's most important communication medium is the radio. Stassen (2003) is of the opinion that Africa will move directly from the logo sphere to the video sphere - a process which has already started.

Concern is often expressed that the Internet may replace the book. One serious consequence of this could be the broadening of the gap between First World and Third World countries - those with access to resources, technology, knowledge and information, and those without. However, the use of the Internet does not necessarily exclude the use of books and printed material. Stassen (2003) is of the opinion that the book will not disappear, but will continue to exist in one way or another.

Kaschula and De Vries (2000) add another dimension to the "oralityliteracy and technology"-debate, by indicating that the different media can supplement one another in surprisingly creative ways. Commenting on the three-way dialectic between the oral word, the written word and the technologised word, Kaschula and De Vries (2000) emphasise the need for further exploration as far as the Internet is concerned:

Today, it is the use of the Internet that has the potential to revolutionise the composition, transmission and reception not only of written literature, but also oral literature, for example poetry. It could be orally performed and simultaneously translated to a global audience through the oral word. Thereafter it could be down-loaded and published in book form.

In the "technologised orality" the oral aspect could be accompanied by the visual as well as the written (Kaschula \& De Vries, 2000). A sensitivity for cultural preferences and traditions can, in combination with the technological possibilities of the Internet, lead to unique applications.

Whereas the acquisition of language and literacy is crucial for personal empowerment and economic development, it goes without saying that providing and promoting children's literature in the 
vernacular can play a significant role in the advancement of literacy. An important question in this regard, then, is whether the Internet can be used as one of the means by which this aim can be achieved.

\section{The Internet in South Africa}

What is the situation in South Africa regarding access to the Internet?

It is estimated that $7,4 \%$ of the people in South Africa are Internet users (Internet World Stats, 2005). Compared to First World countries such as the USA and Norway, in which more than $60 \%$ of the population have access to the Internet, statistics do not appear promising. Added to this is the fact that in South Africa some population groups reflect the situation in the First World countries, while others are on a par with Africa as a whole (with 0,8\% Internet users). Inequalities regarding access to the Internet are a worldwide phenomenon. Industrial countries, which account for $15 \%$ of the world population, represent $88 \%$ of the users of the Internet (Wasserman, 2003:88).

Internet access in South Africa is still largely in line with economic divisions: the "virtual South Africa" mirrors the "real South Africa" (Wasserman, 2003:89). In South Africa $70 \%$ of households use electricity; $73 \%$ of households have radios; $54 \%$ of households have television; $24 \%$ of households have landline telephones; $8,6 \%$ of households have personal computers (National Census, 2001). Of adult South Africans residing in major metropolitan areas, 8,4\% have access to the Internet (white: $20,8 \%$, coloured: $11,0 \%$, Asian: 10,8\%, black: 1,3\%) (Dix, 2003).

Although statistics can be daunting, a new perspective is added when it is realised that South Africa's Internet users represent approximately 3,5 million people - a considerable number compared to some other countries. Norway has, for example, a total population of 4,5 million. The challenge, however, is to provide services for a diverse population such as South Africa's.

In South Africa, the importance of literacy and new communication technologies is recognised by various initiatives and policies, e.g. the Electronic Communications and Transactions Act and the National Education Policy. One of the aims of the latter is the promotion of Information Communication Technology (ICT). 
The Draft White Paper on e-Education (South Africa, 2003) deals with the use of information communication technology (ICT) in society and education. In this document digital literacy is seen as a "life skill" in the same way as literacy and numeracy. Government's response to a new information and communications technology environment accumulates in the e-Education policy goal which states:

Every South African learner in the general and further education and training bands will be ICT capable (that is, use ICT confidently and creatively to help develop the skills and knowledge they need to achieve personal goals and to be full participants in the global community) by 2013.

Strategic objectives to reach the policy goal include ICT professional development, content resource development, infrastructure, connectivity, community engagement, and research and development.

The current profile and distribution of ICT in schools indicate that $26,5 \%$ of schools have computers for teaching and learning. E-mail facilities are increasingly and more extensively used as a management and administrative resource. Although Internet access in schools is becoming more common, the use of the Internet for teaching and learning purposes is very limited. More than 19000 schools are still without computers for teaching and learning (South Africa, 2003).

The implementation of the e-Education policy should in the long run result in the accessibility of digital media and the literacy of its users. It also implies the need for appropriate local content.

The Draft White Paper on e-Education (South Africa, 2003) accentuates the importance of language and local content when stating that the digital divide is not only about connectivity and infrastructure disparities, but also about "local content development in terms of the number and quality of local websites, local language content and the use of local online content by key sectors". The policy framework's strategic objective regarding electronic content resource development and distribution includes the following aspects: the development of e-learning resources, the adaptation and development of local content into indigenous languages, the creation of electronic content, and access to digital libraries.

In her research on "Providing a web-based information resource for Afrikaans First Language teachers", Heyns (2002:91) concludes that 
... although the policy environment in South Africa is conducive to the development of Internet resources, there is still a considerable lack of local content and content for specific subjects. There is a special need for quality resources with indepth information for teachers and learners alike.

She also found that the best sites are those that adhere to the specific information needs of the intended target group, which is especially important to ensure ownership and utilisation by the target population. However, the content of websites available or accessible to children is predominantly in English and children's websites in African languages are almost non-existent.

The emphasis on and increasing use of ICT and the Internet, especially in schools, and the urgent need for local content in indigenous languages, create a golden opportunity for the advancement of children's literature.

\section{Children's literature and the Internet}

The variety of existing websites illustrates the extent to which children's literature has already made use of this medium. These websites are dedicated to all aspects of children's literature as a polysystem, i.e. the production, marketing, mediating and reception of literature.

Some examples of websites and their applications are web portals, which serve as gateways to Internet resources, e.g. Children's Literature Web Guide (www.acs.ucalgary.ca/\%7Edkbrown); informational websites on children's literature and literature organisations, e.g. IBBY (www.ibby.org); libraries and collections such as The International Children's Digital Library (www.icdlbooks.org); websites for writers of children's books (www.write4kids.com) and opportunities for young writers to publish their own creative work on the web (www.kidpub.org/kidpub). Publishers and authors also make use of the Internet to supply information and market their services and books. Target groups comprise of researchers, adult mediators such as parents and teachers, and young users (children and teenagers) themselves.

South African websites for and with content on children's books include those of Unisa's Children's Literature Research Unit (www.childlit.org.za); the Childlitweb of the North-West University (www.puk.ac.za/fakulteite/lettere/SKT/childlitweb); reading and literacy projects such as Masifunde Sonke (www.masifundesonke. 
org.za); authors' websites e.g. Martie Preller (www.martiepreller. co.za); and publishers' marketing material (www.lapa. co.za). The application of the internet does not only entail the use of websites, but also includes other forms of communication via the Internet, for example e-newsletters and e-groups. The Children's Literature Network, an e-group administrated by the Centre for the Book, was set up to act as forum for debate, advice, and sharing of information on children's literature.

The Internet makes it possible for one to create tailor-made costeffective websites for certain purposes and target groups, e.g. children's literature. It also allows for the possibility of using various media (graphics, movement, sound), communication methods and forms (e.g. e-mail, newsgroups, chat rooms and discussion forums) as well as levels of interactivity (e.g. real-time communication). Owing to the flexibility of the Internet, endless combinations are possible: the scope and target group can vary from a simple site promoting a single book to a local community, to a comprehensive site for international purposes including all aspects of the polysystem and using a multitude of methods. The system of interlinkages, use of various forms of communication and interactivity, and the ease and speed of updating content contribute to the dynamic character of the Internet and the unique identity of a particular website.

The creative, innovative, interactive and inviting character of the Internet makes it an important medium to explore in order to advance children's literature. The Internet not only creates the opportunity to promote existing forms of literature for today's children, but also provides new ways to interact with old stories, new possibilities to reflect on experiences, and new ways to create and recreate - paving the way for new genres in children's literature for the next generation.

By creating websites dedicated to children's literature, much can be achieved; even more so if it is done in a user-friendly manner in the user's own language. Apart from providing much needed local content, other advantages include encouraging the culture of reading and writing; contributing to personal, language and cultural identity; promoting children's literature in different languages; and creating new markets.

By adding fun and enjoyment for the user, this kind of website then potentially contributes to language ability and literacy, including digital literacy. The possibility of user participation also presents the 
opportunity to be actively involved in the processes of receiving as well as providing (new) opportunities for reflection, perception, and social experience.

When a new user discovers a relevant website in his or her mother tongue, the benefits for personal, language and cultural identity are evident.

In combining different languages on a website, the appreciation of other languages, literatures and cultures, as well as multilingualism is promoted.

\section{Storiewerf (Story Yard) - an example}

The vast possibilities, technical potential and speed of technological development of the Internet are overwhelming. The saying, "what can be conceived, can be achieved", is certainly applicable to the Internet.

In the development of a website, the designer can easily be tempted to use all the exciting technical possibilities. It is, however, important to consider the feasibility of this. In South Africa the speed of Internet connection (bandwidth) and high connectivity and telecommunication costs are key factors that need to be considered in the conceptualising of Internet applications. Some other factors that must be kept in mind are inter alia the following: available resources (money, people, knowledge); available technology (availability, user/ PC ratio); available content (stories, literature, books, publications in preferred language/s); the intended target group (language, cultural traditions, age, skills) as well as the purpose, function, form and content of a website.

Everything considered, it is possible to create an exciting and interesting website with relatively few resources.

As an example of the possibilities of the Internet for the promotion of children's literature, I want to refer to personal experience in establishing, developing and maintaining a website for Afrikaans children's literature, namely Storiewerf (www.storiewerf.co.za), which has been active since April 2000.

Storiewerf originated in response to the decline in sales of children's books and the increasing marginalisation of Afrikaans, and my desire, as a writer for children, to make a positive contribution to children's books, as well as to pass on the joy of reading and writing to the next generation. 
The central purpose of Storiewerf is the promotion of Afrikaans children's literature, as well as the encouragement of creative writing by the young and the advancement of Afrikaans on the Internet.

Storiewerf (translated "Story Yard") consists of two sections, namely a section for adults and another for young readers. The two sections share a portal and are also linked on every page, which enables easy navigation between the sections. Both sections have a front page which serves as a newspaper and introduction to the website. A monthly e-newsletter keeps subscribers informed of new content on the website.

The section for adults (Grootmense) mainly consists of information on writers, books, reading lists, links, reviews and articles on children's literature. Currently the following pages form part of the adults' section: Werfjoernaal (newspaper), Resensies (reviews), Skakels (links), Leeslys (reading lists), Skrywers (information on children's authors and their publications), Nostalgie (adults' reading experiences and favourite books as children), Dinkskrum (relevant articles), Helpmekaar (users in search of books), Hulpbronne (resources), Werkplaas (articles on writing), Vanwaar gehasi? (about us) and Werfkaart (site map).

In the section for the young (Jongklomp), the focus is on participation. This section includes stories for young readers, news on books, hints on writing, the opportunity to write poems and stories, and the opportunity to participate in competitions. The pages are: Storienuus (newspaper), Kuier by (interviews with writers by young readers themselves), Oondvars (new publications), Lusmakers (paragraphs from new publications), Storiegedorie (young readers' comments on books), Storiemakers (information on writers), Grilgrot (horror stories), Kollig (texts for eisteddfods), Versfabriek (opportunity to write poetry), Skryfgeheime (hints on writing), Vonkelfiksie (prose by young writers), Lapastories (opportunity for second-language users to write their own stories), Verinniewêreld (experiences of South African children in other countries), Haasbekkies (stories for small children), Balkie (Martie Preller's story character), Wedstryd (monthly competitions). Children's publications of LAPA Publishers can also be ordered on the website.

Content for Storiewerf is supplied voluntarily by authors and publishers of Afrikaans children's literature (LAPA, Tafelberg and Human \& Rousseau). Authors contributing on a regular basis are Martie Preller, Marianna Brandt, Jaco Jacobs and Maritha Snyman. 
Students in Creative Writing at the North-West University also contribute to the website. The illustrations are by Piet Grobler, a well-known illustrator of children's books.

The website is used for different purposes by a variety of users. Visitor statistics (Web statistic report, 2004) for Storiewerf for the timeframe August 2003 to July 2004 indicate that an average of 2582 distinct visitors visits Storiewerf each month. Some of these visitors are only casual visitors, but a fair amount visit the site regularly. Understandably statistics show that the bulk of users are from South Africa, but the site also attracts a fair number of worldwide visitors, including visits from the Netherlands $(6,6 \%)$, Belgium (3,7\%), the United Kingdom, Namibia and Australia (Web statistic report, 2004).

As can be expected, the home pages that also serve as navigation pages are the most visited pages (front page, welcome page, Werfjoernaal, Storienuus). The most popular sections are information on writers (Storiemakers en Skrywers), the stories for the young (Haasbekkies), information on new books (Oondvars) and the poetry pages (Versfabriek). Single pages that are frequently visited are pages which provide a service, such as help finding books (Helpmekaar) and links (Skakels). An hourly summary shows that $57,4 \%$ of page requests are during work hours (08:00-16:59) and $42,6 \%$ after hours (16:00-07:95). The daily summary shows that the total percentage of page requests on weekdays is $69,7 \%$ and during weekends $30,3 \%$. The monthly report shows fewer page requests for December and January, the holiday months. These statistics could suggest that users access Storiewerf (and the Internet) mainly from work and possibly also from school premises, but it also suggests considerable use of the website after hours. The pages visited and the demography of users also indicate that Storiewerf is accessed for different reasons by a variety of users. Users include children of all ages, parents, students, teachers, librarians, researchers, authors and publishers.

Storiewerf is widely acknowledged in the world of Afrikaans children's literature, and feedback of users confirms that the website is achieving its goal. Feedback also confirms the potential of the web to become a positive force in identity formation and cultural transition, providing the user with a sense of belonging and own identity.

A few remarks of users are quoted below as an illustration of this statement: 
Ek is mal oor Storiewerf. Hier kan ek rustig Afrikaans lees en sommer baie leer ook. In Duitsland is daar nie enige Afrikaanse boeke te koop nie en daarom lees ek alles wat ek kan op Storiewerf in Afrikaans (Corissa Visser, 8).

Ek sien my bydrae is aangeteken op Storiewerf, en dit is baie, baie, nogmaals baie wonderlik. Ek geniet dit om op Storiewerf te werk. Dit is wonderlik (Danie van der Walt, 13).

Ek wil net sê ek dink die webblad van julle is baie opwindend! Ek is mal oor lees en dit is vir my verskriklik lekker om al die nuutste boeke hier op die webblad te kyk (Sumari Marais, 12).

Ek wil net lees, lees, lees!!!! Baie dankie vir Storiewerf op die web. Skep vir ons nog meer lees, pret en leesgenot. Dit is wonderlik om in ons mooiste Moedertaal, Afrikaans te kan lees en ons kennis te kan verbreed (Louise Conradie, 12).

Ek is 'n finale jaar student in Onderwys. Dis altyd lekker om te sien watter boeke nuut op die mark is en wat ek kan aankoop om te gebruik in die klas eendag. Dankie vir julle puik webblad (Deandra Marais, 22).

Ek is ' $n$ voltydse Rekenaarjuffrou en al die rekenaars het toegang tot internet. Een keer per kwartaal gee ek Gr 1-7 geleentheid om nuwe stories of boeke op Storiewerf te lees. Dit prikkel hulle om dan die boek self te gaan uitneem by die biblioteek. Ek gee ook aan die Gr 6'e \& 7's geleentheid om oor die skrywers navorsing te doen. Soms laat ek hulle ook die limerieke en gedigte lees. Wanneer die ouers hoor dat ek Storiewerf gebruik, is hulle baie verbaas om te hoor dat daar werklik 'n goeie webtuiste vir Afrikaanse Letterkunde is (Martie Dippenaar)

Dis 'n heerlike webwerf, lyk aanloklik en sal sweerlik selfs lui lesers aanspoor om 'n boek te gryp. Baie dankie vir julle geesdrif en harde werk om kinders aan die lees te kry en aan die lees te hou! (Marita van der Vyver).

Die storiewerf het werklik 'n belangrike knooppunt vir jeug- en kinderboeke geword (Leon de Villiers).

\section{Recommendations}

The Internet poses new opportunities for providing and promoting children's literature, while also addressing issues like literacy, linguistic diversity and the use of indigenous languages. 
It can be argued that the propagation of websites for local children's literature is negating the realities of South Africa, wasting precious resources, providing for the privileged few, and contributing to the digital divide. However, considering the importance of informationcommunication technology, its place in the global arena and its assumed role in future, this new communication medium cannot be ignored. It is also important to keep in mind that a child who has already accessed the Internet is a possible future leader (reader) in the process of forming an own identity. Surely this child cannot be deprived of that which is at the heart of humanity: stories in the mother tongue.

Getting to know and use new technology always has its challenges. It is by starting to use the new medium and exploring its possibilities that knowledge is acquired and capacity is built for meaningful and creative future application.

With Storiewerf as a working example, new websites can be developed to provide content and services for other target groups as well. One can start by creating a basic site with available content and expanding it over time. Websites such as these can be linked to a portal for South African children's literature that can serve as a meeting place and point of reference for local children's literature.

When considering the e-Education policy goal and its strategic objectives, teachers would be in the first lineage of new users. (By 2010 fifty percent of teachers are to be trained in basic ICT integration in teaching and learning (South Africa, 2003).) It thus makes sense to keep the school curriculum and the needs of teachers in mind when utilising the Internet for the advancement of children's literature.

One of the strategic objectives of the e-Education Policy Framework (South Africa, 2003) is a national education portal that is linked with provincial and privately-owned portals:

It will be a distributive tool, a content and information-sharing platform, hosting communications and collaboration application for learners, teachers, administrators, managers and parents. It will serve as a nucleus for building web-based resources for teachers, learners and the community, making it possible to create new knowledge and add to the existing knowledge base.

Heyns (2002:92) stresses the need for the urgent development of subject-specific portals for teachers of all learning areas/subjects. A portal such as this could supply reliable and updated information 
resources for teachers and could ease the task of the teacher, while saving precious time spent on searching for information on the Internet.

A portal for local children's literature can be one of the clusters in larger portals, such as a subject-specific and national education portal - thus not only providing valuable content, but also advancing children's literature through its presence and availability.

To ensure success when creating a website for children's literature one needs:

- People committed and dedicated to children's literature.

- Co-operation between different role players, e.g. publishers, authors and web designers.

- Sponsors to provide funding and support.

- The necessary infrastructure, technology and technical support.

- Sensitivity for and knowledge of the cultural environment of the target group.Knowledge of the medium, the user (child or adult), literacy and children's literature.

- A marketing strategy to promote the website.

- The dream, vision, creative energy and knowledge to undertake a project like this.

For South Africa the dream could be to reach people in all the official languages with websites promoting children's literature and the wonderful world of stories.

\section{Conclusion}

The Internet can play a significant role in the creation and transference of cultural identity, including the advancement of indigenous languages in general, and literature and literacy in particular. The vast technical possibilities of the Internet, its costefficiency and interactive and inviting character makes it an important option to consider for the advancement of children's literature. Although access to the Internet in South Africa is still relatively limited, the importance of new communication technologies is recognised by various policies, the implementation of which could result in the accessibility of electronic media and the literacy of its users. With Storiewerf as an example, new websites can be developed to provide content and services for other target 
groups and languages as well, utilising the Internet's unique possibilities for the production, marketing, mediating and reception of children's literature.

\section{List of references}

ANON. 2003. Gr. 3-leerlinge sukkel met skoolwerk. Beeld, June 11.

BURNETT, R. \& MARSHALL, P.D. 2003. Web Theory: An introduction. London: Routledge.

DIX, S. 2003. Looking Beyond the Statistics: The Internet in the Lives of the Emerging Black Market. http://www.webcheck.co.za/library_paper_ emerging.html [26 April 2003].

DU PLESSIS, M. 2003. Personal conversation with Miemie du Plessis, publisher of children's books. Pretoria: LAPA.

GALLOWAY, F. 2002. Statistical trends in SA book publishing during the 1990s. Alternation: Journal for the Centre for the Study of SA Literature and Languages, 9(1):204-225.

GLOBAL REACH. 2003a. Global Internet Statistics (by language). http://www. glreach.com/globstats/index.php3 [16 July 2003].

GLOBAL REACH. 2003b. Global Internet Statistics: Sources \& References. http://global-reach.biz/globstats/refs.php3 [16 July 2003].

HEYNS, D. 2002. Providing a web-based information resource for Afrikaans first language teachers. Pretoria: UP. (Masters' dissertation.)

i-MAG. 2004. Speaking freely on Freedom Day. Media statement by the Multilingualism Action Group (i-MAG). April 27.

KASCHULA, R.K. \& DE VRIES, I. 2000. Indigenous languages and the Internet: With LitNet as a case study. http://www.litnet.co.za/taaldebat/netlan.asp [26 April 2004].

INTERNET WORLD STASTS. 2005. South Africa: Internet usage and marketing report. www.internetworldstats.com/af/za.htm [April 2005].

NATIONAL RESEARCH FOUNDATION. 2003. Education and the challenges for change. http://www.nrf.ac.za/focusareas/educate [22 April 2003].

SISULU, E. 2004. Editorial. Cape Librarian, 48(1):1-2.

SOUTH AFRICA. 1996. South African Constitution 1996. http://www.info.gov. za/constitution/1996/96cons1.htm [6 August 2004].

SOUTH AFRICA. 2003. Draft White paper on e-Education. Transforming learning and teaching through ICT. http://www.gov.za/whitepaper/2003/eeducation.pdf [24 February 2004].

STASSEN, N. 2003. Die laaste (Afrikaanse) boek? http://www.mweb.co.za/ litnet/ seminaar/kknkstassen.asp [4 June 2003].

WALLRAFF, B. 2000. What global language? The Atlantic Online. http://www. theatlantic.com/issues/2000/11/wallraff3.htm [17 July 2003].

WASSERMAN, H. 2003. Globalisering, die internet en Suid-Afrikaanse tale: 'n verkenning van potensiaal en probleme. Tydskrif vir Geesteswetenskappe, 43 (1\&2):81-93

WEB STATISTIC REPORT. 2004. Web statistic report produced by Report Magic for Analog. http://storiewerf.co.za/_system_/statistik [1 August 2004]. 


\section{Key concepts:}

children's literature

internet

language and identity

\section{Kernbegrippe:}

internet

kinderliteratuur

taal en identiteit 